\title{
Political Parties and Foreign Aid
}

Jean-Philippe Thérien and Alain Noël

There is no lack of pleas for a better integration of domestic factors in the analysis of foreign policy and international relations. The idea that international politics is shaped by the internal politics of states stems from an old, diversified, and enduring tradition of international relations (Waltz 1954). In recent years, this tradition has been rejuvenated by the growing recognition that the most fundamental transformations of our time cannot be explained by international factors alone (Kratochwil 1993, 63). Yet, the relationship between domestic and international politics remains poorly understood. So far, research has consisted mostly in testing diverse factors that may influence foreign policy, such as public opinion, bureaucratic conflicts or state strength. Piecemeal, these studies appear unsatisfactory and tend to lose sight of politics (Putnam 1988, 430-33). With the logic of two-level games, Robert D. Putnam and others have offered a more integrated framework for situations of international negotiations (Evans, Jacobson and Putnam 1993; Milner 1997). Many international developments, however, do not involve negotiations. International cooperation, for instance, can be achieved through mutual adjustments, "without direct communication between the participants" (Keohane 1984, 76). In such cases, and probably for negotiations as well, the two-level game rationalist focus on leaders "forced to balance domestic and international concerns" may be misplaced, as proponents of the approach recognize (Evans 1993, 401 and 428). A broader, more historical perspective on domestic politics is required and, for this, we must turn to comparative politics. In this article, we use the literature on political parties and on the welfare state to assess, with a structural equation model, the impact of partisan orientations and domestic institutions on foreign aid.

The growing integration of the world economy has raised questions on the policy options left to national governments and on the relevance of partisan politics (Scharpf 1991, 244-48; Kurzer 1993, 252). Recent studies have reaffirmed the influence of partisan orientations on domestic public policy, but the debate remains open on the magnitude and the nature of this 
influence (Rhodes 1996; Boix 1998; Clayton and Pontusson 1998; Garrett 1998a and 1998b; Swank 1998). The idea that "parties make a difference" appears even more problematic for international relations. After Ernst B. Haas' classical work on European integration, few studies of the domestic sources of foreign policy have dealt with political parties in a systematic, comparative manner (Haas 1958; Risse-Kappen 1991; Holsti 1991, 192-93; Simmons 1994, 281). Traditionally understood as above parties, beyond the water's edge, foreign policy has been portrayed either as consensual or as idiosyncratic, more associated with leaders and circumstances than with partisan orientations (Nincic 1992, 90-91). A few exceptions concern issues where policy is easier to measure - such as defense spending, international trade, and foreign aid - but even in these cases, much remains to be done (see, respectively: Chan and Mintz 1992; Verdier 1994; Noël and Thérien 1995).

This article starts from the idea that parties and institutions matter, and that they do so not only domestically, but also with respect to foreign policy. We argue that, at least for development assistance, parties make a difference. Leftist parties, in particular, have an impact on a country's level of foreign aid. This impact, however, works in the long-run, through the mediation of welfare institutions and social spending practices. In other words, partisan politics plays a role, but it does so within the broader and more enduring context of domestic structures. Beyond the immediate issue of foreign aid, these findings contribute to the larger debates on the relevance of parties and on the domestic sources of foreign policy, because they help specify the effects of partisan politics and the channels that lead from domestic conflicts to foreign conduct.

The first part of the article surveys the literature on political parties and foreign aid, and finds that existing studies are inconclusive. The second part proposes a new theoretical model, from which we derive two hypotheses regarding the long-run influence of social-democratic and Christian-democratic parties on development assistance. The third and fourth parts present the data used in this analysis and the results we obtained with a LISREL structural equation model. The last part draws on comparative politics to explain the different national cases. It shows, more specifically, how partisan orientations make a difference in foreign aid policy and how 
their impact is mediated by other institutional variables. The conclusion discusses the implications of this study for the broader debate on the integration of domestic and international politics.

\section{State of the Art}

Traditionally, the literature on the domestic foundations of foreign policy has focused on mass and elite opinion, without much reference to domestic institutions and collective political actors (Hudson 1995, 219; Risse-Kappen 1991, 484-85). More recent studies have dealt with various non-governmental actors, such as interest groups, multinational corporations and the media, but surprisingly little has been done on political parties (Gerner 1995, 21). Case studies exist, particularly on the workings of multiparty coalition governments, but few analyses provide a comparative perspective (Hagan 1993, 26-31; and 1995, 137). This neglect is surprising given the centrality of political parties in the government of liberal democracies, their importance in the study of public policy, and their acknowledged role in some key foreign policy changes (Blais, Blake and Dion 1993, 40; Hagan 1994, 139).

In this context, one would expect few well-established findings on the more specific issue of political parties and foreign aid. There is in fact some good work on this question, in part because foreign aid lends itself well to measurement and international comparisons, and also because many students of development assistance have adopted a perspective which stresses the domestic determinants of foreign conduct. Most of the studies on the parties-aid relationships are qualitative, but a few have used a quantitative methodology.

Qualitative studies suggest political parties have an influence on foreign aid. From his seminal comparative study of the "like-minded countries" (Canada, Denmark, the Netherlands, Norway, and Sweden), Olav Stokke concludes that the efforts made to maintain the question of foreign aid "above party politics" do "not imply...that the political colour of a government does not matter" $(1989,281)$. Parties of the left, in particular, would be more generous toward Third 
World countries than parties of the right. Common sensical, this proposition seems corroborated by a number of observations. As Stokke explains, the Nordic countries, where social-democratic parties have been in power for a long period, rank among the leading development assistance contributors. Conversely, countries like Japan and the United States, where social-democratic parties are absent or have virtually no influence, maintain a foreign aid effort constantly below the Organization for Economic Cooperation and Development (OECD) average. In the 1980s, these observations were reinforced by the contrasted evolution of France and the United Kingdom. With the Socialists in power, France increased its assistance, just as the Conservative government of Margaret Thatcher reduced its aid budget (Adda and Smouts 1989, 34-35; Byrd 1991, 60-61). In a major study, David H. Lumsdaine has reaffirmed the "left-does-matter" thesis for the entire community of aid donors. For him, "parties with strong socialist or domestic redistributive concerns...strengthened aid when in power, while conservative governments tended to retrench" $(1993,163)$. According to Lumsdaine, governments project their domestic orientations on the international scene. More committed to equality and social spending at home, parties of the left would be predisposed to spend more on development assistance as well.

Although with much less emphasis, qualitative analyses also suggest that, like religious groups, Christian parties tend to be favorable to development assistance (Cooper and Verloren van Themaat 1989, 82; Pratt 1989, 195; Lumsdaine 1993, 158). Drawing a parallel between the social principles supported by Christian democrats and social democrats, Stokke argues that the norms in which Christian democracy is rooted are conducive to a generous stance toward the Third World because "these norms are universal and do not stop at the borders of nation states" $(1996,22)$. In countries like Sweden, Norway, Denmark, and the Netherlands, religious parties or party factions have indeed mobilized behind foreign aid (Södersten 1989, 189; Kärre and Svensson 1989, 263; Stokke 1989, 282). Other cases, however, indicate the situation is far from clear-cut. In Italy, for instance, Christian democrats have been dominant for the entire post-war period, but the government has maintained one of the lowest foreign aid contributions among 
OECD countries. Overall, in the qualitative literature, the impact of religious parties on aid policy does not appear as well established as that of leftist parties.

Quantitative studies of the parties-aid relationships have dealt only with the influence of leftist parties on development assistance and, even on this question, they appear much less conclusive than qualitative studies. Louis-Marie Imbeau examined 17 countries over the 19631981 period, using the percentage of votes obtained by each party as an indicator of party strength (1988; 1989). He found that "more left-oriented countries give more aid" but acknowledged the fragility of his results $(1989,109)$. Of the four years considered by Imbeau, only two (1976 and 1981) yielded a significant and positive measure of association; one year (1966) even presented a negative correlation between the power of the left and the level of foreign aid. With such "ambiguous" results, Imbeau finally concluded that "what is important seems not to be which ideology is present, but rather how it is translated into policy" (157). For Imbeau, the role played by parties must be understood as complementary to other factors, such as inertia, donor's interests, and donor's perceptions of recipients' needs (155).

Marijke Breuning's work also suggests there is no simple, straightforward relationship between partisan orientations and development assistance. Her content analysis of parliamentary debates on foreign aid in three countries (Belgium, the Netherlands, and the United Kingdom) shows, for the 1975-91 period, that "the political affiliation of the minister has the potential to affect the debate in Parliament as a whole"; yet, the same analysis indicates that "whatever agenda-setting the ministers do...is not determined by their party affiliation" $(1995,246)$. Breuning's conclusions reinforce the traditional view of foreign policy as standing beyond partisan differences, since she finds "a consensus about the state's role in the foreign assistance issue area" (252).

A recent study of 16 countries over the 1965-1988 period, by Alain Noël and JeanPhilippe Thérien, supports the skepticism of Imbeau and Breuning. Using the difference between the percentage of seats in the cabinet held by parties of the left and of the right as an indicator of leftist power, Noël and Thérien find no correlation between the parties in power and 
the level of foreign aid. For three of the six years considered, they even obtain negative correlations. These authors suggest, however, further tests should be conducted, given the plausibility of the partisan hypothesis, established by a host of qualitative observations and studies $(1995,532)$.

The constrast between qualitative studies agreeing that parties matter and quantitative ones failing to confirm this idea is striking. In these circumstances, a lack of quantitative support should not lead us to dismiss hastily the conclusions of qualitative assessments. The hypothesis of a relationship between partisan orientation and development assistance may have been tested the wrong way. There are many indicators of partisan strength, and a variety of models to capture the relationship between parties and policy.

\section{Theoretical Model}

In comparative politics, the debate over partisan influence has generated a host of more or less contradictory studies (Blais, Blake and Dion 1993 and 1996; Schmidt 1995). The main lesson that can be drawn from this debate is that if parties have an impact, they do not have a strong, universal, and obvious one. Parties are omnipresent, concludes Manfred G. Schmidt, but they are not omnipotent $(1995,8)$. There are, at least, three problems with the conventional representation of partisan influence. First, the usual conceptualization and measurement of partisan variables assume governments have immediate impacts, and they fail to capture the long-run dimension of partisan politics. Second, most quantitative studies of parties and public policy neglect the importance of Christian democracy, importance underlined in recent studies of European politics. Third, the standard understanding of partisan influence looks only at direct effects, assuming there is always a simple, unmediated relationship between parties and public policies. Our theoretical model addresses these three issues, to better account for the partiesforeign aid relationships. 
The first problem concerns the time frame of partisan influence. The usual indicators of partisan strength measure, in various ways, the distribution of power in a given year. This shortterm perspective may well explain why quantitative studies have failed to confirm the widespread observation that "in country after country, the politicians and political parties that strongly advocated aid were those on the left" (Lumsdaine 1993, 139). The impact of social democracy on public policy is likely to be a long-run phenomenon, felt only after a party has been in power for many years. In foreign as in domestic policy, patterns tend to be established at critical junctures, to change only incrementally thereafter. The dominance of a party over a long period probably matters more than the distribution of power at any point in time. This is what Evelyne Huber, Charles Ragin and John D. Stephens demonstrate in their work on the welfare state. With cumulative indicators of partisan power, these authors obtain more conclusive results than previous studies on the impact of parties (1993, 724-25). Accordingly, our model of the partisan determinants of development assistance includes variables measuring the cumulative presence of parties in power and compares them to more conventional, one-year only, indicators of partisan power.

The second problem concerns the role of religious parties. As explained above, the specific contribution of Christian-democratic parties to foreign aid policy has been recognized in the qualitative literature but omitted in quantitative studies. Until recently, the situation was similar in the comparative study of the partisan foundations of the welfare state. Understood as historical anomalies or as functional equivalents of social-democratic or conservative parties, Christian-democratic parties were largely neglected, except in case studies (van Kersbergen 1995, 1-2 and 23-29; Kalyvas 1996, 1-7). Recent works, however, have established the distinctive and coherent character of Christian democracy as a centrist phenomenon, characterized by its emphasis on social mediation and moderate policies (van Kersbergen 1995, 28-29; Kalyvas 1996, 263-64). Christian-democratic parties have constructed distinct welfare states that institutionalized their conceptions, inspired by religious ideas, of social capitalism and societal accommodation (van Kersbergen 1995, 2-5 and 230-31). Qualitative studies suggest 
similar dynamics have been at play with respect to foreign aid. Two political traditions, insists Stokke, have shaped foreign aid policies: the first derives from the social-democratic understanding of solidarity and the second from the Christian-democratic notion of brotherhood (1996, 22-24). A model seeking to explain the impact of parties on development assistance should therefore include a variable for Christian democracy, alongside the more conventional variable measuring social-democratic power. This new variable should also, of course, be considered in the long-run, to capture the effect of Christian-democratic cumulative power.

Finally, existing quantitative studies assume there is a direct, unmediated relationship between partisan orientations and foreign aid. This assumption is associated with the conventional idea that parties have an independent impact on each policy area; they would implement their platform section by section, in a straigthforward fashion. This understanding of public policy as a set of distinct items may be reinforced by the use of multiple regression techniques to test the assumed relationships. While they may suggest the presence of indirect effects, regressions provide an image of policy as determined by a set of independent variables, whose effects are additive more than interactive. "The multiple regression equation," write Randall E. Schumacker and Richard G. Lomax, "is by definition additive and does not permit any relational specification of variables. This limits the potential for variables to have direct, indirect, and total effects on each other" $(1996,38)$. The historical institutionalist approach to comparative politics offers a useful theoretical corrective. Indeed, beyond their claim that institutions matter, historical institutionalists seek to "demonstrate the relationships and interactions among a variety of variables in a way that reflects the complexity of real political situations" (Thelen and Steinmo 1992, 13). Their aim is to develop "more explicit theorizing on the reciprocal influence of institutional constraints and political strategies and, more broadly, on the interaction of ideas, interests, and institutions" (Thelen and Steinmo 1992, 14). In this perspective, the model we propose indicates how the interactions between partisan and other institutional variables may account for foreign aid. More specifically, this model associates 
partisan power to social-democratic welfare state institutions and social spending, two variables previously identified as significant in the explanation of foreign aid.

To sum up, we propose a model of the parties-foreign aid relationships that is novel in three major ways. First, this model considers partisan cumulative power, assuming partisan effects are a long-run phenomenon. Second, it includes a variable for Christian democracy to integrate an important insight of the qualitative studies on foreign aid and of the recent literature on the welfare state. Third, our model starts from the idea that partisan effects may be indirect, and incorporates potentially important intervening variables, social-democratic welfare state institutions and social spending. Combined with what is already known about parties, the welfare state and foreign aid, these three propositions yield two hypotheses:

$\mathrm{H}_{1}$ : Left cumulative power has a positive effect on foreign aid, through the influence of socialist attributes and social spending.

$\mathrm{H}_{2}$ : Religious cumulative power has a positive effect on foreign aid, through the influence of social spending.

In the first hypothesis, the logic at work is the following: when they hold power for a long period, parties of the left tend to institutionalize social-democratic welfare state principles and practices, which are themselves the best predictors of a country's foreign aid effort. The second hypothesis derives from the observation that Christian-democratic cumulative power favors high levels of social spending, and that a country's social spending is strongly associated with its foreign aid (Huber, Ragin and Stephens 1993; Noël and Thérien 1995).

Methodologically, our hypotheses involve a series of interrelated effects that can best be represented and tested with a structural equation model. Theoretically, our approach stems from the general idea that, for political parties, the road to power requires the construction of social bases, a continuous process that involves transforming the state to institutionalize various forms of social solidarity and class alliances (Esping-Andersen 1985, 37-38). In the process, certain 
ideas and principles prevail and are entrenched for long periods, during which they shape not only the actors' strategies, but also their goals and their discourses, often in more than one policy area (Thelen and Steinmo 1992, 9). This is why foreign aid is closely linked to the domestic social policies that parties have built over time.

\section{The Data}

Our model includes one dependent variable (Foreign Aid), two independent variables for left and religious party strength (measured in two different ways), and two additional independent variables that have proved important in accounting for a country's development assistance commitment (Socialist Attributes and Social Spending). ${ }^{1}$ The analysis is comparative and cross-sectional. It includes the most important aid donors, 16 of the 20 countries belonging to the OECD Development Assistance Committee (DAC), for two different years, 1980 and $1991 .^{2}$

The dependent variable, foreign aid, is measured with OECD data on official development assistance (ODA) as a percentage of GNP (OECD, various years, Development Cooperation). ${ }^{3}$ With respect to partisan orientations, we use two types of indicators to measure the strength of leftist and religious parties. Both derive from the comparative literature on the influence of political parties and are based, with some adjustments, on Francis G. Castles and Peter Mair's classification (1984). The two types of indicators are very different theoretically and empirically. The first type (Left Power and Religious Power) reflects the current distribution of partisan power, in a given year. Left power is borrowed from André Blais, Donald Blake and Stéphane Dion, and measures "the difference between the percentages of seats in the cabinet held by parties of the left and of the right" $(1993,48)$. We calculated religious power in a similar fashion, as the percentage of cabinet seats held by religious parties, for each year under study. The second type of indicators (Left Cumulative Power and Religious Cumulative Power) was 
developed by Huber, Ragin and Stephens, and measures left and religious party power over the years. Unlike the first type of indicators, which gives discrete values for each year considered, this second type provides scores that are additive from 1946 onward. The measure of party strength is also somewhat different. Whereas left power and religious power consider the percentage of seats in the cabinet, left cumulative power and religious cumulative power use the fraction of leftist/religious seats in parliament of all governing parties' seats (Huber, Ragin and Stephens 1993, 725). The key difference, of course, concerns the instantaneous impact expected with the first type of indicators, compared to the stress on cumulated power associated with the second type. We have argued above that cumulative indicators of partisan power appear preferable because they better represent the historical strength of the different parties. These indicators may be unstable in the early years, when a shift in government can modify a country's score markedly, but they become stable for the later years that we consider in this cross-sectional study (1980 and 1991). In any case, the comparison of year-to-year and cumulative indicators of partisan power should help us clarify their respective merits.

We had the opportunity to work with data sets provided by Blais, Blake and Dion and by Huber, Ragin and Stephens. ${ }^{4}$ The Blais, Blake and Dion data were used as expanded and corrected in the authors' most recent analysis $(1996,515)$. The Huber, Ragin and Stephens data, which ended in 1988, were updated to 1991 with the help of data compiled in the European Journal of Political Research (Woldendorp, Keman and Budge 1993; Koole and Mair 1993).

The two additional independent variables (socialist attributes and social spending) were established as important domestic determinants of foreign aid by Noël and Thérien (1995). We adopt these authors' definitions and sources. Socialist attributes are represented by Gøsta Esping-Andersen's scores, which capture the degree of program universalism in a country's welfare state. ${ }^{5}$ Social spending is represented by total social transfers as a percentage of GNP. Transfers are the sum of the OECD National Accounts data for "social security benefits" and “social assistance grants" (OECD, various years, National Accounts). 
The analysis is cross-sectional and is conducted for two years, 1980 and 1991. These two years are distant enough, and sufficiently recent to speak of mature welfare states and of a fully established international aid regime (Noël and Thérien 1995, 529). The first year is the one for which Esping-Andersen's scores are compiled. The second is the most recent year for which a complete data set was available. Following other welfare state scholars, we assume the socialist attributes scores compiled for 1980 held constant to 1991 (Janoski 1994, 56; Stephens 1996). Strictly speaking, this is probably not true. Welfare states have changed and some countries have abandoned earlier commitments to universality (Pierson 1994). Overall, however, it seems fair to speak of a "frozen welfare state landscape" (Esping-Andersen 1996, 24). Institutions change slowly; welfare state institutions, in particular, have proved particularly resilient in the face of important challenges (Pierson 1996).

\section{Results}

To explore the various relationships between our different variables, we start with bivariate and multivariate estimations, and then develop a structural equation model. First, we must compare our two types of indicators of partisan strength. This is done in Table 1, which presents the relationships between partisan orientations and foreign aid for 1980 and 1991, as well as the other bivariate relationships necessary to build our model.

TABLE 1. Correlations Among Political Variables and Foreign Aid, 1980 and 1991

\begin{tabular}{|c|c|c|c|c|c|c|}
\hline & \multicolumn{3}{|c|}{1980} & \multicolumn{3}{|c|}{1991} \\
\hline & $\begin{array}{l}\text { Socialist } \\
\text { Attributes }\end{array}$ & $\begin{array}{c}\text { Social } \\
\text { Spending }\end{array}$ & $\begin{array}{l}\text { Foreign } \\
\text { Aid }\end{array}$ & $\begin{array}{l}\text { Socialist } \\
\text { Attributes }\end{array}$ & $\begin{array}{l}\text { SocialForeign } \\
\text { Spending }\end{array}$ & Aid \\
\hline $\begin{array}{l}\text { Left } \\
\text { Power }\end{array}$ & .26 & .13 & .08 & .14 & $.48^{*}$ & .31 \\
\hline Religious & .17 & $.58 *$ & .10 & .22 & $.17 \quad .22$ & \\
\hline
\end{tabular}




\begin{tabular}{|c|c|c|c|c|c|c|c|}
\hline Power & & & & & & & \\
\hline $\begin{array}{l}\text { Left } \\
\text { Cumulative } \\
\text { Power }\end{array}$ & $.76^{* *}$ & $.27 \quad .52^{*}$ & & $.70 * *$ & .43 & $.66^{* * *}$ & \\
\hline $\begin{array}{l}\text { Religious } \\
\text { Cumulative } \\
\text { Power }\end{array}$ & -.31 & $.56^{*}$ & -.06 & & -.28 & $.32-.19$ & \\
\hline $\begin{array}{l}\text { Socialist } \\
\text { Attributes }\end{array}$ & & .27 & $.77 * *$ & & & $.52 *$ & $.88 * *$ \\
\hline $\begin{array}{l}\text { Social } \\
\text { Spending }\end{array}$ & & & $.62 *$ & & & & $.73 * *$ \\
\hline
\end{tabular}

The first indicator of Table 1, left power, represents the current strength of the left in cabinet in a given year. It does not account significantly for foreign aid. Noël and Thérien obtained the same result for 1965, 1970, 1975, 1980 and 1988, and concluded that "while parties may matter in the formulation of aid policies...left-right partisan orientations do not generate a statistically significant explanation of foreign aid behavior" $(1995,532)$. The second indicator of left party strength, however, yields very different results. Left cumulative power, the indicator borrowed from Huber, Ragin and Stephens, is strongly and positively associated with foreign aid, for both 1980 and 1991. This result reconciles the quantitative evidence with qualitative accounts that stress the role of political parties in development assistance policies. It also indicates how partisan influence operates.

Parties do not have on foreign aid the year-to-year impact suggested by an indicator like left power; their influence is felt over the years, as power, so to speak, is cumulated. This mechanism operates in other issue areas as well. Left cumulative power, for instance, "shows significant correlations with measures of income distribution and redistribution" (Huber, Ragin and Stephens 1993, 740). Huber, Ragin and Stephens' indicator embodies an understanding of power and public policy that is more structural than pluralist. What matters, in this perspective, 
is not simply to form a government, but also to exercise and to keep power. A party's influence is directly related to its capacity to govern for long periods. This understanding of partisan influence seems fitting for a study of development assistance since the level of a country's foreign aid does not change frequently or abruptly.

Table 1 also shows there is no correlation between our two indicators of religious partisan strength and foreign aid. ${ }^{6}$ Bivariate analysis, however, offers only a partial view of the relationships involved. Religious cumulative power, for instance, may not be correlated with foreign aid, but in 1980 it is a significant determinant of social spending, which is itself associated with foreign aid. Even the left cumulative power-foreign aid relationship may not be as straightforward as suggested by the results of Table 1. In a multiple regression including other determinants of foreign aid identified in the theoretical model, the left cumulative powerforeign aid relationship becomes non-significant. Table 2 presents the results of this regression for 1980 and 1991.

\section{TABLE 2. Regression Testing Hypothesized Predictors of Foreign Aid for 1980 and 1991}

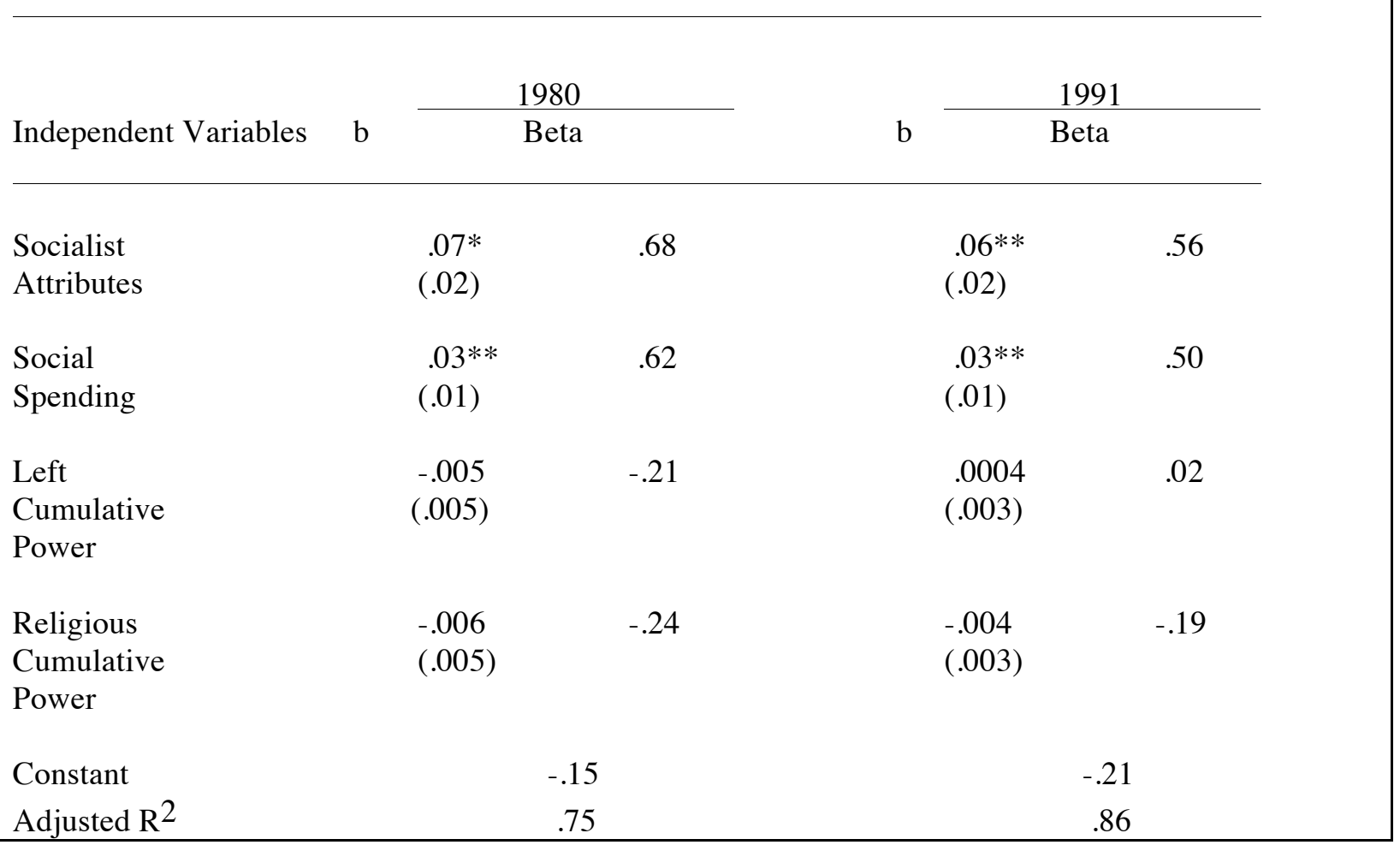


F-value

$12.24 * *$

$24.91 * *$

Note: Standard errors are in parentheses.

$* p<0.05 ; * * p<0.01$.

By themselves, socialist attributes and social spending provide a good explanation of foreign aid (adjusted $\mathrm{R}^{2}$ of .74 in 1980 and .86 in 1991). As is clear from Table 2, the addition of left cumulative power and religious cumulative power does not significantly improve these results (adjusted $\mathrm{R}^{2}$ of .75 in 1980 and .86 in 1991). ${ }^{7}$ Our aim, however, is not simply to account for foreign aid in the most parsimonious way, but also to elucidate the role played by political parties, both directly or indirectly.

Consider the impact of leftist parties. We know from Table 1 that left cumulative power is associated with foreign aid. When left cumulative power is combined with socialist attributes and social spending in a multiple regression, however, it becomes non-significant. This is consistent with our hypothesis about the role of social-democratic parties and institutions: the relationship between left cumulative power and foreign aid seems to be a typical case of developmental sequence, with socialist attributes and social spending as intervening variables (Asher 1976, 18).

In the case of religious parties, the situation is more complex. As is shown in Table 1, the relationship between religious cumulative power and foreign aid is not significant. When social spending is added as an independent variable in a multiple regression, however, religious cumulative power becomes significant, but the relationship is negative (Beta of -.60 in 1980, $p<.05$; and -.47 in 1991, $p<.01$ ). Hence, not only does Christian-democratic power have no direct effect but, when social spending is held constant, it even works against foreign aid. While religious cumulative power does increase social spending, which is associated with increased 
foreign aid, it appears that any impact of religious parties on foreign aid is unimportant or even negative.

To better understand the indirect and total effects of parties on foreign aid, we will use a structural equation model. A technique derived from multiple regression and path analysis, structural equation modeling makes it possible to integrate in a single model the two paths that may lead from political parties to foreign aid, and to estimate simultaneously all the possible effects. This technique also provides an assessment of the overall explanatory power of the combined variables. Covariance matrices were analysed, and the parameters of the models were estimated with maximum likelihood fitting function (LISREL 8.12). Figure 1 presents the complete model, with the results for both years under study. 
FIGURE 1. Causal Relationships Among Hypothesized Predictors and Foreign Aid, with LISREL Estimates, 1980/1991

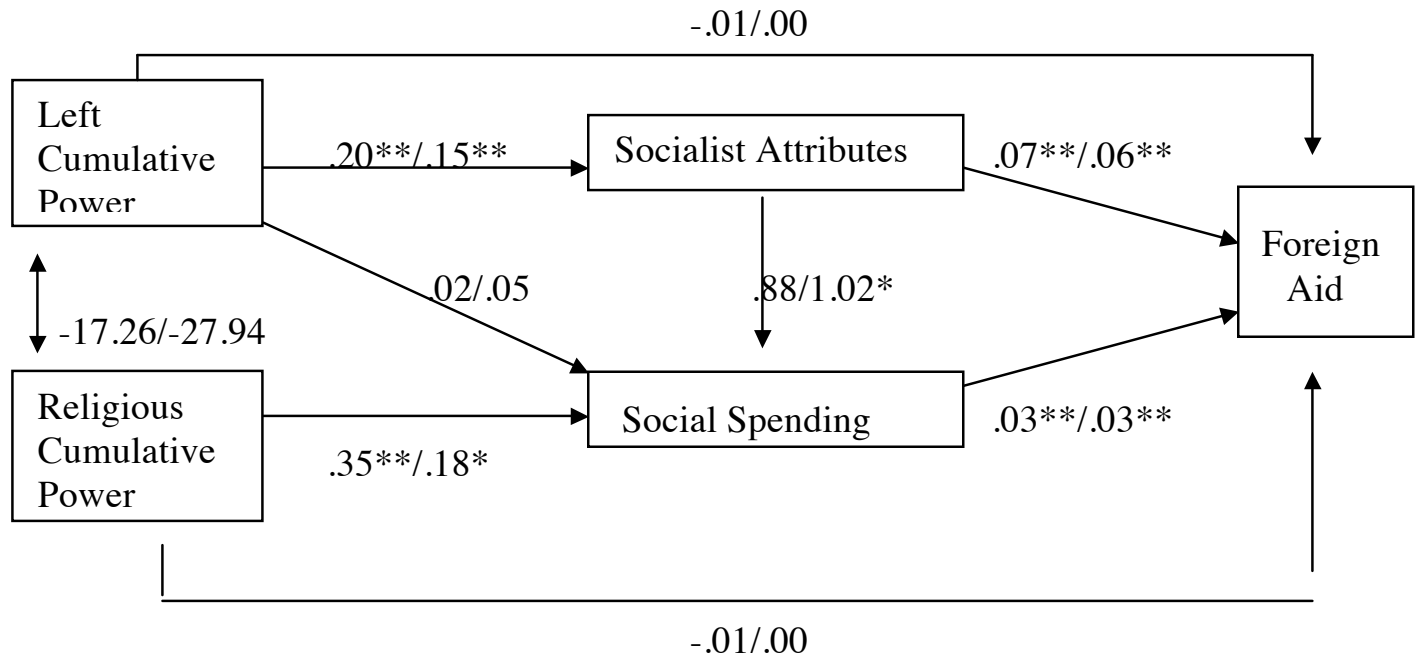

Note: Figure entries are unstandardized coefficients.

$\chi^{2} \quad 1.25$ with 1 degree of freedom; probability level $=.26(1980)$

.74 with 1 degree of freedom; probability level $=.39(1991)$

GFI $\quad .97(1980)$ and $.98(1991)$

NNFI $\quad .94(1980)$ and $1.06(1991)$

IFI $\quad 1.00(1980)$ and $1.00(1991)$

$* p<0.05 ; * * p<0.01$

This structural model is adequate, and it clarifies the role of left cumulative power and religious cumulative power in explaining foreign aid. The most commonly used indices of model fit are satisfying. The probability level of the chi-square statistic (.26 for 1980 and .39 for 1991) suggests a good model fit (Jaccard and Wan 1996, 86). The Goodness of Fit Index (GFI), the Non-Normed Fit Index (NNFI), and the Incremental Fit Index (IFI) also indicate that our model is consistent with the data (Marsh, Balla and Hau 1996; Tanaka 1993). We also tested the similarity of the 1980 and 1991 models, following Bollen's testing hierarchy $(1989,355-59)$. 
We started with the less restrictive hypothesis, where both models have the same dimensions and the same pattern of fixed, free, and constrained elements in parameter matrices. The results indicated an excellent fit to the data $\left(\chi^{2}=1.998\right.$, $\mathrm{df}=2$, and $\left.p=.368\right)$. More restrictive hypotheses also show a good fit. Even under the most restrictive one, where all parameter matrices are constrained to be equal, the fit to the data is excellent $\left(\chi^{2}=9.664\right.$, $\mathrm{df}=16$, and $p=$ .884). A comparison of the most and of the least restrictive hypotheses gives results that are consistent with the assumption that the same logic operates in both years $\left(\chi^{2}=7.666, \mathrm{df}=14\right.$, and $p=.906)$. With all the parameters stable over time, the 1980 and 1991 models appear equivalent. ${ }^{8}$

This structural equation model lends support to our first hypothesis on the impact of left partisan orientation, but not to the second one, on religious parties. A country's development assistance effort is shaped by socialist welfare state attributes and government social spending, two variables that are themselves associated with the influence that social-democratic parties have established over the years. Contrary to what is often suggested by casual observations in the literature on foreign aid, however, religious parties do not seem to have an impact on development assistance. Table 3 summarizes the impact of each independent variable on foreign aid by providing its unstandardized total effect.

TABLE 3. Total Effects of Hypothesized Predictors on Foreign Aid, 1980 and 1991

\begin{tabular}{lcc}
\hline & 1980 & 1991 \\
\hline Left Cumulative Power & $.01^{*}$ & $.02^{* *}$ \\
Religious Cumulative Power & .01 & .00 \\
Socialist Attributes & $.09^{* *}$ & $.09^{* *}$ \\
Social Spending & $.03^{* *}$ & $.03^{* *}$ \\
& & \\
Note: Table entries are unstandardized coefficients. & &
\end{tabular}


$* p<0.05 ; * * p<0.01$

In both years, the total effect of left cumulative power was significant, and so were the total effects of socialist attributes and social spending. Overall, the pattern is the same for 1980 and 1991, except that the total effect of left cumulative power on foreign aid is higher in 1991. The total effect of religious cumulative power is weaker and non significant.

Our model helps understand the role played by partisan orientations in the shaping of foreign aid policies. The level of a country's development assistance is significantly linked, through socialist welfare state attributes and government social spending, to the historical power of the left, but not to that of Christian-democratic parties. The effect of social-democratic parties is neither immediate nor prevailing nor direct. First, the impact of these parties appears only over time, when we use indicators of cumulative partisan power. Second, their direct effect is not as strong as that of welfare state attributes and social spending; in multiple regressions including these two variables, left cumulative power is not significant. Third, the paths that lead from partisan strength to foreign aid work through a country's welfare institutions and practices. These more distant but very real relationships explain the stress placed on parties by qualitative studies and the absence of confirmation in quantitative analyses.

\section{From the Model to the Cases}

To discuss more specifically the relationship between left cumulative power and foreign aid, it is useful to consider three categories of countries, according to the strength of their socialdemocratic tradition. Table 4 presents these three categories, with left cumulative power and religious cumulative power for 1991, socialist attributes for 1980, and an average of foreign aid spending levels for the 1971-1991 period. 
Table 4. Independent Variables and 1971-91 Average for Foreign Aid as a Percentage of GNP, by Country

\begin{tabular}{|c|c|c|c|c|c|}
\hline & $\begin{array}{l}\text { Left } \\
\text { Cumulative } \\
\text { Power } \\
(1991)\end{array}$ & $\begin{array}{l}\text { Religious } \\
\text { Cumulative } \\
\text { Power } \\
(1991)\end{array}$ & $\begin{array}{l}\text { Socialist } \\
\text { Attributes } \\
\\
(1980)\end{array}$ & $\begin{array}{l}\text { Social } \\
\text { Spending } \\
(1991)\end{array}$ & $\begin{array}{l}\text { Foreign } \\
\text { Aid } \\
(1971-91)\end{array}$ \\
\hline Sweden & 38.61 & 0.04 & 8 & 17.08 & .80 \\
\hline Norway & 33.88 & 2.04 & 8 & 14.87 & .88 \\
\hline Austria & 28.63 & 16.96 & 2 & 15.27 & .23 \\
\hline Denmark & 25.39 & 0.35 & 8 & 17.05 & .71 \\
\hline Finland & 19.27 & 0.03 & 6 & 7.06 & .33 \\
\hline United Kingdom & 16.16 & 0 & 4 & 10.40 & .37 \\
\hline Australia & 15.77 & 0 & 4 & 8.28 & .48 \\
\hline Belgium & 14.13 & 24.48 & 4 & 22.07 & .51 \\
\hline Germany & 12.31 & 25.43 & 4 & 14.73 & .40 \\
\hline Switzerland & 11.65 & 13.33 & 4 & 12.17 & .24 \\
\hline France & 11.34 & 3.97 & 2 & 17.20 & .45 \\
\hline Netherlands & 9.70 & 29.04 & 6 & 24.88 & .86 \\
\hline Italy & 4.91 & 37.07 & 0 & 14.08 & .22 \\
\hline Canada & 0 & 0 & 4 & 10.16 & .46 \\
\hline Japan & 0 & 0 & 2 & 10.07 & .27 \\
\hline United States & 0 & 0 & 0 & 9.85 & .23 \\
\hline
\end{tabular}

Over the 1946-1991 period, Sweden, Norway, Austria, and Denmark stand out as the only countries where the left has been in power for the equivalent of more than half of the time. For Sweden, Norway, and Denmark, the pattern is clear. Social democrats prevailed over most of the period, they established typical socialist welfare institutions, and maintained high levels of social spending and a strong record as three of the most committed aid donors of the OECD. These countries, and the Netherlands, are the only ones to have reached the $0.7 \%$ of GNP target set by the international community. Austria, on the other hand, seems to be an odd case. Despite a strong social-democratic party, in power for many years, this country has a foreign aid record comparable to that of countries where the left is weak or absent, such as Italy, Japan, and the United States. In this case, the explanation lies in welfare state institutions. Established by 
conservative governments, and left essentially untransformed by the Austrian Socialist Party (SPÖ), Austria's welfare state is typically conservative, with almost none of the universalist programs that characterize social-democratic institutions (Esping-Andersen 1990, 53 and 60; Esping-Andersen and Korpi 1984, 194). Alone in power from 1970 to 1983 and involved in coalition governments for most of the remaining years of the period, the SPÖ has pursued a moderate, catch-all strategy, more akin to that of centrist parties than to that of hegemonic socialdemocratic ones (Gerlich 1987, 85-86; Kitschelt 1994, 178). In power for many years, the Austrian socialists governed in a conservative fashion; they did not establish social-democratic institutions and did not commit their country to a generous foreign aid policy.

In Finland, the United Kingdom, Australia, Belgium, Germany, Switzerland, France, and the Netherlands, the left did not prevail over the 1946-1991 period, but it played a role, being in power, alone or in coalition, for the equivalent of ten years or more (9.7 in the Netherlands). Most of the countries that belong to this middle cluster have an average score for socialist welfare state attributes, which means that they have institutionalized universality in some of their social programs, in health care for instance. Accordingly, they tend to have average development assistance contributions. With a strong but not predominant left, most of these countries integrated social-democratic elements in their welfare institutions and made substantial efforts to increase their aid budget. In this group, two countries - Switzerland and the Netherlands - stand out for their atypical aid behavior.

Switzerland appears less generous than expected, given the cumulative power of its left parties and its average score for socialist welfare attributes. This result can be explained by the nature of the Swiss party system. The average cumulative score of the Swiss Socialists results from their regular representation in governmental coalitions; this representation, however, is always contained within alliances that limit ideological conflicts (Kerr 1987, 119-21). In this context, explains Henry H. Kerr, "the Swiss parliament appears more to register decisions taken elsewhere - be it at the polls or in antechambers of the administration - than to shape coherent policy in response to recognizable party programmes" (140). The presence of Socialists in 
government has not challenged the dominant conservative ideology of the country (Kerr 1987, 182). In spite of its average socialist attributes, Switzerland also remains a welfare laggard. One of the least redistributive countries of the OECD, it contributes relatively little to the international aid regime (Katzenstein 1984, 111; Castles and Mitchell 1992, 22).

The Netherlands, on the other hand, is more generous than expected. With the lowest left cumulative power score in the middle cluster, this country has a foreign aid contribution comparable to that of the Scandinavian countries, well above the $0.7 \%$ international objective. Again, explanations can be found in the country's party system. In the 1950s, social policy cemented the alliance between the Catholic Peoples' party (KVP) and the social democrats (Partij van de Arbeid). Taking advantage of favorable economic conditions, these parties laid the foundations of a generous welfare state. These foundations were not challenged with the demise of the "Roman-red" coalition (van Kersbergen 1995, 132-33). On the contrary, in the 1960s, faced with electoral decline and confronted by radicalized Catholic trade unions, the Catholic party allied with the Protestant parties (Antirevolutionary party and Christian Historical Union), and these parties pursued social-democratic policies to preserve their power against the left, in a competitive and fragmented political space. To "bolster electoral support," the confessional parties "became the advocates of the adoption of universal programs that provide more generous benefits than anything the Labor party strove to realize" (Cox 1993, 169). Against the opposition of a left concerned by costs, the religious parties, "whose ideology espouses a parochial version of the limited state," became "responsible for one of the biggest welfare expansions in the world" (Cox 1993, 218-19). In a country where the left was not so strong, socialist welfare state institutions were promoted by religious parties and, along with them, a political situation conducive to a remarkable expansion of foreign aid.

The last group of cases includes countries where the left is weak or absent: Italy, Canada, Japan, and the United States. The results for Italy, Japan, and the United States are straightforward. With a weak left and almost no socialist welfare state attributes, these countries are predictably among the less generous aid donors. The Canadian case appears more puzzling 
since it has average foreign aid levels, which themselves correspond to average socialist welfare state attributes. The case is somewhat akin to that of the Netherlands, with a centrist party pushed by the left to adopt reforms. In the $1945-1975$ period, when the contemporary Canadian welfare state was built, the New Democratic Party (NDP) was never in power at the federal level, but it remained a significant competitor for the dominant Liberal party. The NDP was also in power at the provincial level, where some of the major social reforms originated. In this context, the Liberal party institutionalized universal social programs, and created a welfare state favorable to the development of foreign aid (Thérien and Noël 1994, 548).

With religious parties, the situation appears quite different. The Christian democrats' commitment to redistribute income abroad remains well below that of social democrats; when we control for social spending, religious parties even work against foreign aid. As van Kersbergen explains, Christian democrats built a distinct type of welfare state regime, which emphasizes societal accommodation and embodies a specific understanding of social justice (1995, 204 and 231). This welfare state, however, can vary significantly across countries, according to the competitive environment faced by Christian democrats. In the Netherlands, in a highly competitive situation, confessional political forces contributed to the development of a universalist welfare state and raised social spending; accordingly, they adopted a generous stance toward the Third World. In Italy, on the other hand, Christian-democratic dominance did not foster universalist social policies or foreign aid. This was not for lack of power: "No single party in any Western democracy has been able to become so politically dominant in the first decades after the Second World War as the Italian Democrazia Cristiana” (van Kersbergen 1995, 59). This political force did not permit many social policy innovations because reform-minded Christian and social democrats remained isolated within their parties, and unable to count on a strong communist movement that would not support gradual change. The result was a minimalist, fragmented welfare state, which was "more an effect of the incapacity to act and to reform than the result of intentional intervention" (van Kersbergen 1995, 162-67). Not 
surprisingly, the impulse behind development assistance also remained weak (Alessandrini 1984).

The paths that lead from left cumulative power to socialist welfare state attributes and social spending, and then to foreign aid account for much of the cross-country variance in development assistance levels. Few exceptions can be singled out, and these exceptions can be explained by the peculiar logic of party competition in the different countries. In fact, these exceptions can help understand the interest and the limits of the variables considered and of the model that is proposed. While the cumulative partisan scores prove useful, they are not faultless indicators of partisan power. First, adding up years of presence in coalition governments may exagerate the real influence of a party that never governs alone and rarely prevails. The Swiss score, for example, overstates the strength of the left in a predominantly conservative country. Second, the sum of years in power may also fail to represent the extent to which a party is or is not hegemonic. The difference between the Swedish Social Democrats and the British Labour party, for instance, is anchored in each party's ability to forge alliances with other political forces and to define the public policy debate. In Sweden, social democracy became hegemonic; in Britain, liberalism prevailed (Pontusson 1988; Kitschelt 1994, 265). Third, it is important to stress that there is never a perfect correspondence between partisan labels and political behavior (Kitschelt 1994, 108-109). The cases of the Netherlands and Canada remind us that different roads led to contemporary social and foreign aid policies, and that as strategic actors, political parties always retain the capacity to go beyond the boundaries set by their own ideology.

\section{Conclusion}

The findings presented in this article help understand how foreign aid is shaped by domestic politics. The model proposed here confirms the primacy of welfare state socialist attributes and government social spending in the explanation of development assistance policies. At the same time, it shows, contrary to previous quantitative studies of the topic, that political 
parties do matter, not directly and in the short run, but indirectly and over the years. Our findings lend support to the intuition of qualitative studies that have long emphasized the role of partisan cleavages in the formulation of foreign aid policies. For scholars interested in parties, the model could also be useful, since it offers a new assessment of partisan effects. It confirms the empirical relevance of cumulative scores of partisanship and shows how social-democratic power operates through other political determinants.

Most international relations scholars agree that the question is not any more to determine whether or not domestic explanations should be integrated with international ones, but rather to establish how exactly this can be done (Moravscik 1993, 8). In our opinion, it is imperative to look closely at domestic conflicts and to do so with the help of the comparative politics literature. This study suggests that political parties, welfare institutions and social spending play a significant role in the aid policy process, probably because parties and the welfare state "render some ideas more politically influential than others" (Yee 1996, 93). As is explained in the theoretical model section, when parties hold power for a long period, they put forward specific conceptions of social justice that become established as central to a country's political debates. Foreign aid, in particular, appears strongly influenced by "the capacity of a society to accept and institutionalize nonmarket principles of income redistribution" (Noël and Thérien 1995, 549). The exact processes through which this influence becomes effective and evolves can only be assessed with case studies. Our findings are consistent with a host of such studies, as well as with Lumsdaine's observation that "the parties that supported aid were those concerned with issues of equality and alleviation of poverty, not those concerned with the free market or with military and strategic issues" $(1993,179)$. The impact of these concerns is felt mainly in the long run, as parties establish their primacy in society and as their ideas become institutionalized. The partisan history of Scandinavia and Britain, for instance, has shaped these countries' public debates: "liberalism and social democracy have been hegemonic ideological forces in the arena of political reasoning for close to a century. They have structured the political dialogue around questions of liberty and equality, individual property rights and the central government's power 
to intervene in the marketplace, social class and citizenship" (Kitschelt 1994, 265). We agree that such public debates matter, and argue that they matter not only for domestic politics but also for foreign policy. 
Notes

${ }^{1}$ We also considered the rate of unemployment and the consumer price index, two independent variables that reflect the economic context within which countries make their development assistance decisions. In simple regressions, however, the relationship between the rate of unemployment and foreign aid is not significant (adjusted $\mathrm{R}^{2}$ of -0.07 for both 1980 and 1991). The relationship between the consumer price index and foreign aid also proves nonsignificant (adjusted $\mathrm{R}^{2}$ of -0.06 in 1980 and -0.07 in 1991).

${ }^{2}$ In 1991, these 16 countries provided $94.3 \%$ of total world aid (OECD 1995).

${ }^{3}$ The choice of this measure can be justified easily. First, it constitutes the standard indicator in the literature on foreign aid. Second, other measures of a country's commitment to development assistance - the multilateral character of the country's contribution, the grant-loan ratio, or the proportion of aid that is untied - tend to correspond to its overall level of foreign aid (Lumsdaine 1993, 41-42 and 268). Third, this indicator is politically meaningful since the international community expresses aid targets in these terms (Opeskin 1996, 22).

${ }^{4}$ We are grateful to the authors, who shared their data with us and offered helpful advices.

${ }^{5}$ Esping-Andersen gives a score of 0 when 60 percent or less of the population between ages 16 and 65 is covered by a sickness, unemployment, or pension program, a score of 2 when coverage is between 61 and 85 percent, and a score of 4 when more than 85 percent of the working-age population is covered. Socialist attributes are the sum of these scores for the three programs (Esping-Andersen 1990, 73-78).

${ }^{6}$ With a historically strong Christian-democratic party and a low level of foreign aid, it could 
be hypothesized that Italy distorts the effect of religious power. To assess this possibility, all tests were conducted without the case of Italy. The results were essentially the same.

${ }^{7}$ To make sure one or two cases are not driving the findings, we have screened the data to detect univariate and multivariate outliers. Univariate outliers were inspected using standardized scores for each variable and multivariate outliers were sought with Mahalanobis distance. No outliers were identified: the largest score for univariate outliers was 2.24 and the smallest probability for multivariate outliers was $p=0.103$. Partial residual plots were also examined and no departure from linearity was found.

${ }^{8}$ Since the variables are likely to contain random and systematic errors, we reestimated the models assuming measurement error. There is no information in the literature about the reliability of the measures we used, but it seems reasonable to consider that socialist attributes has the lowest reliability, followed by left cumulative power and religious cumulative power, and then by social spending and foreign aid. Four variants of the models were estimated, assuming a range of reliability from 0.5 to 0.7 for socialist attributes, from 0.6 to 0.7 for partisan variables, and from 0.7 to 0.9 for social spending and foreign aid. In each case, for both years, it is impossible to assess the impact of measurement errors on the model because residual variances are negative and $\mathrm{R}^{2}$ larger than one. Further, the number of iterations necessary for the models to converge is too high for the solutions to be valid. No conclusion can be drawn about the potential impact of measurement errors on the models. 


\section{References}

Adda, Jacques and Marie-Claude Smouts. 1989. La France face au Sud: le miroir brisé. Paris: Karthala.

Alessandrini, Sergio. 1984. "Italian Aid: Policy and Performance." In European Development Assistance. Volume I: Policies and Performance, ed. Olav Stokke. Tilburg: University of Tilburg Press and European Association of Development Research and Training Institutes.

Asher, Herbert B. 1976. Causal Modeling. Sage University Paper series on Quantitative Applications in the Social Sciences, 07-003. Beverly Hills: Sage.

Blais, André, Donald Blake and Stéphane Dion. 1993. "Do Parties Make a Difference? Parties and the Size of Government in Liberal Democracies." American Journal of Political Science 37 (February): 40-62.

Blais, André, Donald Blake and Stéphane Dion. 1996. "Do Parties Make a Difference? A Reappraisal.” American Journal of Political Science 40 (May): 514-20.

Boix, Carles. 1998. Political Parties, Growth and Equality: Conservative and Social Democratic Strategies in the World Economy. Cambridge: Cambridge University Press.

Bollen, Kenneth A. 1989. Structural Equations with Latent Variables. New York: John Wiley \& Sons. 
Breuning, Marijke. 1995. "Words and Deeds: Foreign Assistance Rhetoric and Policy Behavior in the Netherlands, Belgium, and the United Kingdom.” International Studies Quarterly 39 (June): 235-54.

Byrd, Peter. 1991. "Foreign Policy and Overseas Aid.” In Britain's Overseas Aid Since 1979: Between Idealism and Self-Interest, eds. Anuradha Bose and Peter Burnell. Manchester: Manchester University Press.

Castles, Francis G. and Peter Mair. 1984. "Left-Right Political Scales: Some 'Expert' Judgements.” European Journal of Political Research 12 (March): 73-88.

Castles, Francis G. and Deborah Mitchell. 1992. "Identifying Welfare State Regimes: The Links Between Politics, Instruments, and Outcomes." Governance 5 (January): 1-26.

Chan, Steve and Alex Mintz, eds. 1992. Defense, Welfare, and Growth. London: Routledge.

Clayton, Richard and Jonas Pontusson. 1998. "Welfare State Retrenchment Revisited: Entitlement Cuts, Public Sector Restructuring, and Inegalitarian Trends in Advanced Capitalist Societies.” World Politics 51 (October): 67-98.

Cooper, Charles and Joan Verloren van Themaat. 1989. "The Netherlands: Principles and Pragmatism.” In Internationalism under Strain: The North-South Policies of Canada, the Netherlands, Norway, and Sweden, ed. Cranford Pratt. Toronto: University of Toronto Press. 
Cox, Robert H. 1993. The Development of the Dutch Welfare State: From Workers' Insurance to Universal Entitlement. Pittsburgh: University of Pittsburgh Press.

Esping-Andersen, Gøsta. 1985. Politics Against Markets: The Social Democratic Road to Power. Princeton: Princeton University Press.

Esping-Andersen, Gøsta. 1990. The Three Worlds of Welfare Capitalism. Princeton: Princeton University Press.

Esping-Andersen, Gøsta. 1996. "After the Golden Age? Welfare State Dilemmas in a Global Economy." In Welfare States in Transition: National Adaptations in Global Economies, ed. Gøsta Esping-Andersen. London: Sage and United Nations Research Institute for Social Development.

Esping-Andersen, Gøsta and Walter Korpi. 1984. "Social Policy as Class Politics in Post-War Capitalism: Scandinavia, Austria, and Germany.” In Order and Conflict in Contemporary Capitalism: Studies in the Political Economy of Western European Nations, ed. John H. Goldthorpe. Oxford: Oxford University Press.

Evans, Peter B. 1993. "Building an Integrative Approach to International and Domestic Politics: Reflections and Projections.” In Double-Edged Diplomacy: International Bargaining and Domestic Politics, eds. Peter B. Evans, Harold K. Jacobson and Robert D. Putnam. Berkeley: University of California Press. 
Evans, Peter B., Harold K. Jacobson and Robert D. Putnam, eds. 1993. Double-Edged Diplomacy: International Bargaining and Domestic Politics. Berkeley: University of California Press.

Garrett, Geoffrey. 1998a. Partisan Politics in the Global Economy. Cambridge: Cambridge University Press.

Garrett, Geoffrey. 1998b. "Global Markets and National Politics: Collision Course or Virtuous Circle?.” International Organization 52 (Autumn): 787-824.

Gerlich, Peter. 1987. "Consociationalism to Competition: The Austrian Party System Since 1945." In Party Systems in Denmark, Austria, Switzerland, the Netherlands, and Belgium, ed. Hans Daalder. New York: St. Martin's Press.

Gerner, Deborah J. 1995. “The Evolution of the Study of Foreign Policy.” In Foreign Policy Analysis: Continuity and Change in Its Second Generation, eds. Laura Neack, Jeanne A. K. Hey and Patrick J. Haney. Englewood Cliffs: Prentice-Hall.

Haas, Ernst B. 1958. The Uniting of Europe: Political, Social, and Economic Forces, 1950-1957. Stanford: Stanford University Press.

Hagan, Joe D. 1993. Political Opposition and Foreign Policy in Comparative Perspective. Boulder: Lynne Rienner.

Hagan, Joe D. 1994. "Domestic Political Regime Change and Foreign Policy Restructuring: A Framework for Comparative Analysis." In Foreign Policy Restructuring: How 
Governments Respond to Global Change, eds. Jerel A. Rosati, Joe D. Hagan and Martin W. Sampson III. Columbia: University of South Carolina Press.

Hagan, Joe D. 1995. "Domestic Political Explanations in the Analysis of Foreign Policy." In Foreign Policy Analysis: Continuity and Change in Its Second Generation, eds. Laura Neack, Jeanne A. K. Hey and Patrick J. Haney. Englewood Cliffs: Prentice-Hall.

Holsti, K. J. 1991. Change in the International System: Essays on the Theory and Practice of International Relations. Aldershot: Edward Elgar.

Huber, Evelyne, Charles Ragin and John D. Stephens. 1993. "Social Democracy, Christian Democracy, Constitutional Structure, and the Welfare State." American Journal of Sociology 99 (November): 711-49.

Hudson, Valerie, with Christopher S. Vore. 1995. "Foreign Policy Analysis Yesterday, Today, and Tomorrow." Mershon International Studies Review 39 (October): 209-238.

Imbeau, Louis-Marie. 1988. “Aid and Ideology.” European Journal of Political Research 16: 328.

Imbeau, Louis-Marie. 1989. Donor Aid - the Determinants of Development Allocations to Third World Countries: A Comparative Analysis. New York: Peter Lang.

Jaccard, James and Choi K. Wan. 1996. LISREL Approaches to Interaction Effects in Multiple Regression. Sage University Paper series on Quantitative Applications in the Social Sciences, 07-114. Thousand Oaks: Sage. 
Janoski, Thomas. 1994. "Direct State Intervention in the Labor Market: The Explanation of Active Labor Market Policy from 1950 to 1988 in Social Democratic, Conservative, and Liberal Regimes." In The Comparative Political Economy of the Welfare State, eds. Thomas Janoski and Alexander M. Hicks. Cambridge: Cambridge University Press.

Kalyvas, Stathis N. 1996. The Rise of Christian Democracy in Europe. Ithaca: Cornell University Press.

Kärre, Bo and Bengt Svensson. 1989. “The Determinants of Swedish Aid Policy.” In Western Middle Powers and Global Poverty: The Determinants of the Aid Policies of Canada, Denmark, the Netherlands, Norway, and Sweden, ed. Olav Stokke. Uppsala: The Scandinavian Institute of African Studies.

Katzenstein, Peter J. 1984. Corporatism and Change: Austria, Switzerland, and the Politics of Industry. Ithaca: Cornell University Press.

Keohane, Robert O. 1984. After Hegemony: Cooperation and Discord in the World Political Economy. Princeton: Princeton University Press.

Kerr, Henry H. 1987. “The Swiss Party System: Steadfast and Changing.” In Party Systems in Denmark, Austria, Switzerland, the Netherlands, and Belgium, ed. Hans Daalder. New York: St. Martin's Press.

Kitschelt, Herbert. 1994. The Transformation of European Social Democracy. Cambridge: Cambridge University Press. 
Koole, Ruud and Peter Mair, eds. 1993. "Political Data Yearbook 1992," European Journal of Political Research 24: 361-572.

Kratochwil, Friedrich. 1993. "The Embarassment of Changes: Neo-Realism as the Science of Realpolitik Without Politics.” Review of International Studies 19 (January): 63-80.

Kurzer, Paulette. 1993. Business and Banking: Political Change and Economic Integration in Europe. Ithaca: Cornell University Press.

Lumsdaine, David H. 1993. Moral Vision in International Politics: The Foreign Aid Regime 1949-1989. Princeton: Princeton University Press.

Marsh, Herbert W., John R. Balla and Kit-Tai Hau. 1996. “An Evaluation of Incremental Fit Indices: A Clarification of Mathematical and Empirical Properties." In Advanced Structural Equation Modeling: Issues and Techniques, eds. George A. Marcoulides and Randall E. Schumacker. Mahwah, New Jersey: Lawrence Erlbaum.

Milner, Helen V. 1997. Interests, Institutions, and Information: Domestic Politics and International Relations. Princeton: Princeton University Press.

Moravcsik, Andrew. 1993. "Introduction: Integrating International and Domestic Theories of International Bargaining.” In Double-Edged Diplomacy: International Bargaining and Domestic Politics, eds. Peter B. Evans, Harold K. Jacobson and Robert D. Putnam. Berkeley: University of California Press. 
Nincic, Miroslav. 1992. Democracy and Foreign Policy: The Fallacy of Political Realism. New York: Columbia University Press.

Noël, Alain and Jean-Philippe Thérien. 1995. "From Domestic to International Justice: The Welfare State and Foreign Aid.” International Organization 49 (Summer): 523-53.

OECD. Various years. Development Co-operation: Annual Review. Paris: OECD.

OECD. Various years. National Accounts, vol. 2, Detailed Tables. Paris: OECD.

OECD. 1995. Development Co-operation: Annual Review. Paris: OECD.

Opeskin, Brian R. 1996. "The Moral Foundations of Foreign Aid.” World Development 24 (January): 21-44.

Pierson, Paul. 1994. Dismantling the Welfare State? Reagan, Thatcher, and the Politics of Retrenchment. Cambridge: Cambridge University Press.

Pierson, Paul. 1996. “The New Politics of the Welfare State.” World Politics 48 (January): 14379.

Pontusson, Jonas. 1988. Swedish Social Democracy and British Labour: Essays on the Nature and Conditions of Social Democratic Hegemony. Cornell Studies in International Affairs, Western Societies Program, Occasional Paper No. 19, Ithaca, Center for International Studies, Cornell University. 
Pratt, Cranford. 1989. "Middle Power Internationalism and North-South Issues: Comparisons and Prognosis.” In Internationalism under Strain: The North-South Policies of Canada, the Netherlands, Norway, and Sweden, ed. Cranford Pratt. Toronto: University of Toronto Press.

Putnam, Robert D. 1988. "Diplomacy and Domestic Politics: The Logic of Two-Level Games." International Organization 42 (Summer): 427-60.

Rhodes, Martin. 1996. "Globalization and West European Welfare States: A Critical Review of Recent Debates.” Journal of European Social Policy 6: 305-327.

Risse-Kappen, Thomas. 1991. "Public Opinion, Domestic Structure, and Foreign Policy in Liberal Democracies.” World Politics 43 (July): 479-512.

Scharpf, Fritz W. 1991. Crisis and Choice in European Social Democracy. Ithaca: Cornell University Press.

Schmidt, Manfred G. 1995. "The Parties-Do-Matter Hypothesis and the Case of the Federal Republic of Germany." German Politics 4 (December): 1-21.

Schumacker, Randall E. and Richard G. Lomax. 1996. A Beginner's Guide to Structural Equation Modeling. Mahwah, New Jersey: Lawrence Erlbaum.

Simmons, Beth A. 1994. Who Adjusts: Domestic Sources of Foreign Economic Policy During the Interwar Years. Princeton: Princeton University Press. 
Södersten, Bo. 1989. "Sweden: Towards a Realistic Internationalism.” In Internationalism under Strain: The North-South Policies of Canada, the Netherlands, Norway, and Sweden, ed. Cranford Pratt. Toronto: University of Toronto Press.

Stephens, John D. 1996. "The Scandinavian Welfare States: Achievements, Crisis, and Prospects." In Welfare States in Transition: National Adaptations in Global Economies, ed. Gøsta Esping-Andersen. London: Sage and United Nations Research Institute for Social Development.

Stokke, Olav. 1989. "The Determinants of Aid Policies: Some Propositions Emerging from a Comparative Analysis." In Western Middle Powers and Global Poverty: The Determinants of the Aid Policies of Canada, Denmark, the Netherlands, Norway, and Sweden, ed. Olav Stokke. Uppsala: The Scandinavian Institute of African Studies.

Stokke, Olav. 1996. "Foreign Aid: What Now?" In Foreign Aid Towards the Year 2000: Experiences and Challenges, ed. Olav Stokke. London: Frank Cass.

Swank, Duane. 1998. "Funding the Welfare State: Globalization and the Taxation of Business in Advanced Market Economies." Political Studies 46 (September): 671-692.

Tanaka, J. S. 1993. "Multifaceted Conceptions of Fit in Structural Equation Models." In Testing Structural Equation Models, eds. Kenneth A. Bollen and J. Scott Long. Newbury Park, California: Sage.

Thelen, Kathleen and Sven Steinmo. 1992. "Historical Institutionalism in Comparative Politics." In Structuring Politics: Historical Institutionalism in Comparative Analysis, eds. Sven 
Steinmo, Kathleen Thelen, and Frank Longstreth. Cambridge: Cambridge University Press.

Thérien, Jean-Philippe and Alain Noël. 1994. "Welfare Institutions and Foreign Aid: Domestic Foundations of Canadian Foreign Policy." Canadian Journal of Political Science 27 (September): 529-58.

van Kersbergen, Kees. 1995. Social Capitalism: A Study of Christian Democracy and the Welfare State. London: Routledge.

Verdier, Daniel. 1994. Democracy and International Trade: Britain, France, and the United States, 1860-1990. Princeton: Princeton University Press.

Waltz, Kenneth N. 1954. Man, the State and War: A Theoretical Analysis, New York : Columbia University Press.

Woldendorp, Jaap, Hans Keman and Ian Budge, eds. 1993. "Special Issue: Political Data 19451990; Party Government in 20 Democracies." European Journal of Political Research 24: 1-119.

Yee, Albert S. 1996. “The Causal Effects of Ideas on Policies.” International Organization 50 (Winter): 69-108. 


\section{Appendix: Data Values}

TABLE A1. Left and Religious Cumulative Power, Socialist Attributes, Social Spending and Foreign Aid (1980 and 1991)

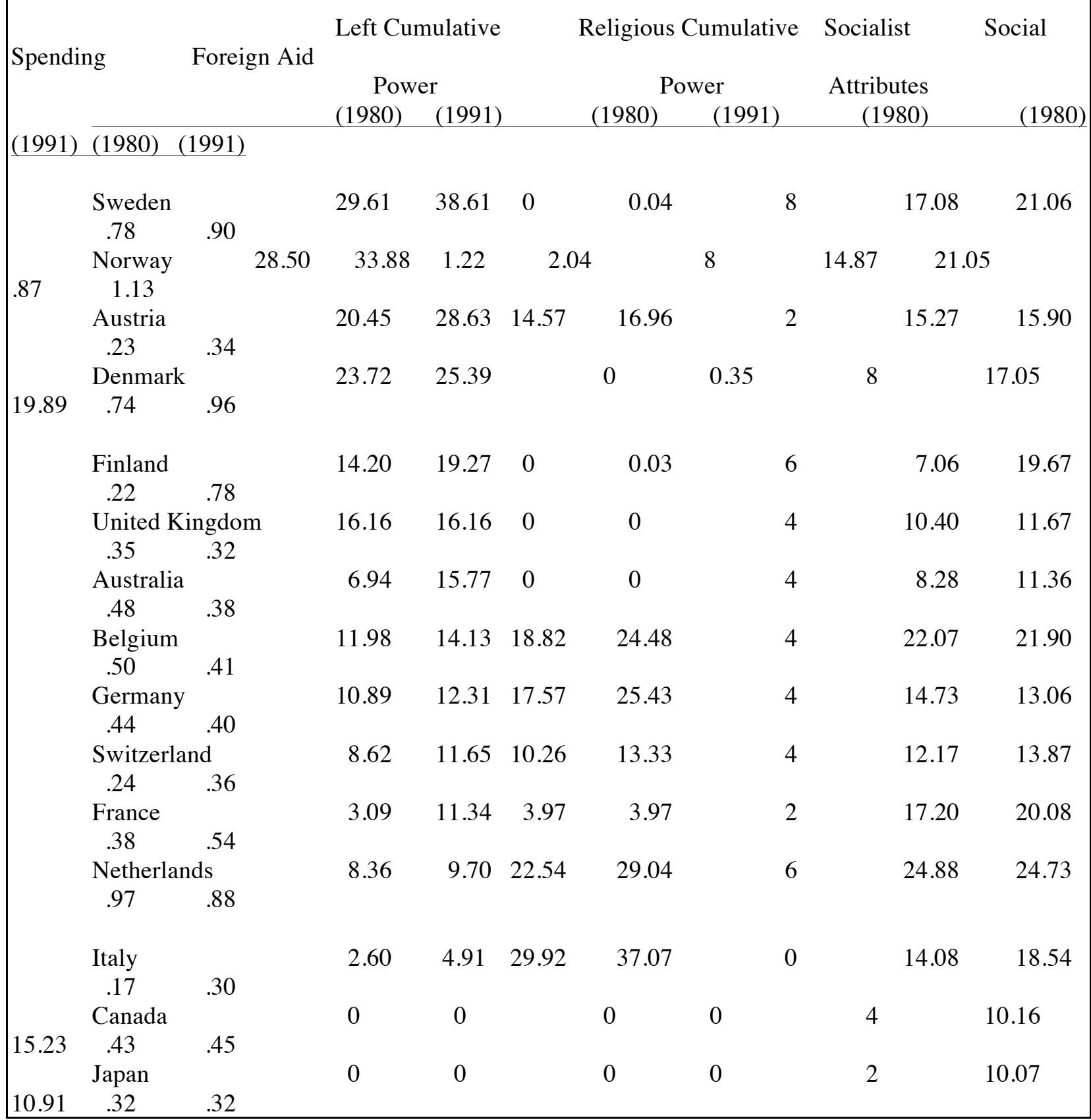




\begin{tabular}{|lccccccccc|}
\hline & United States & 0 & 0 & 0 & 0 & 0 & 9.85 \\
11.04 & $.27 \quad .20$ & & & & & & & \\
& & & & & & & & & \\
\hline
\end{tabular}

